\title{
ISLAMISASI TRADISI: \\ STUDI ANLISIS TERHADAP MARTAHI MARPEGEPEGE PADA BATAK ANGKOLA DALAM PERSPEKTIF HUKUM ISLAM
}

\section{Sylvia Kurnia Ritonga, Lc, M.Sy}

Fakultas Syariah dan Ilmu Hukum IAIN Padangsidimpuan

Email: tsumabi@gmail.com

$$
\begin{aligned}
& \text { ملخص } \\
& \text { مرتاحي مرفغي-فغي هو تقليد راسخ في مختمع بتفانولى جنوبية أو سمي به باتك انكولا غالبًا. هذا } \\
& \text { التقليد هو تقليد يهدف إلى المساعدة من المقربين لأولكك الذين سيتزوجون أبنائهم في مسألة مال الذى هرى } \\
& \text { التي سيعطها لعائلة البنات سيجوجه في العروس أو ما يسمى بولي أو طوخر . ولمساعدته فقام به التعاون } \\
& \text { المتبادل على شكل إعطاء من النقود لأوليك الذين يتزوجون من أبنائه بشرط أن يتم إعادقم عندما يقوم } \\
& \text { بالحاجة الموساويا أيضًا أو سمي هذا بالدين في العريف. فلذلك ليس هناك الضمان في استرداد هذا }
\end{aligned}
$$

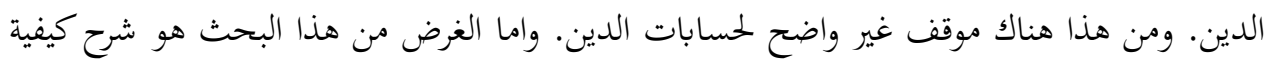

$$
\begin{aligned}
& \text { تطبيق مفاهيم مرتاحي مرفغي-فغي وموقعه في الشريعة الإسلامية. هذا البحث هو بحث نوعي ، حيث } \\
& \text { يتم أخذ البيانات عن طريق إجراء مقابلات مع القادة والملاحظات التقليدية حول تنفيذ مرتاحي } \\
& \text { مرفغي-فغي في فادنغ لواس سمالية. وبعد إجراء هذا البحث ، وجد فيه أن تقليد مرتاحي مرفغي-فنغي }
\end{aligned}
$$

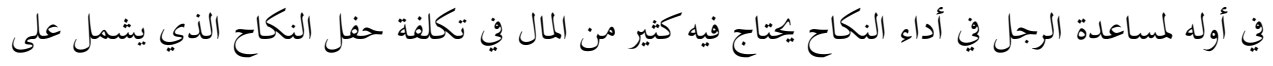

$$
\begin{aligned}
& \text { تنفيذ حدث مرتاحي مرفغي-فغي نفسه ، مهر ، لباس خاص في النكاح، كتاب النكاح، الدرج في }
\end{aligned}
$$

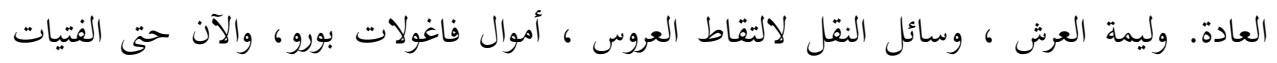

$$
\begin{aligned}
& \text { المتزوجات قاموا بتنفذها. من هذه الدراسة أن تقاليد مرتاحي مرفغي-فغي في الشرعية الإسلامية تشمل } \\
& \text { على أورف صحيح لان ليست في عبادة المخضة وتساعد بشكل متبادل بين الناس ، وخاصة أوليكك } \\
& \text { الضعفاء اقتصاديًا. } \\
& \text { كلمة المفاتيح : التقليد ، السريعة الإسلامية }
\end{aligned}
$$

\section{Abstrak}

Tradisi martahi Marpege-pege merupakan tradisi yang sudah mengakar pada masyarakat Tapanulis Bagian Selatan (TABAGSEL) atau yang sering di berinama Batak Angkola. Tradisi ini adalah tradisi dengan tujuan bantu-membantu dari karib kerabat kepada yang yang akan menikahkan 
anak laki-lakinya dalam hal pembiayaan pernikahan yang akan diberikan kepada keluarga mempelai perempuan atau yang disebut dengan Boli atau Tuhor ni boru. Maka untuk membantunya diadakanlah gotong royong berupa pemberian sejumlah uang kepada yang akan menikahkan anak laki-lakinya dengan catatan dikembalikan ketika pemberi juga melaksanakan seperti yang sama atau utang adat. Maka utang adat ini tidak bisa di pastikan dikembalikan atau tidak. Maka dari hal ini ada ketidak jelasan posisi hutang piutang. Tujuan peneltian ini adalaha untuk menjelskan bagaiman konsep pelaksanaan tradisi Martahi Mapege-pege dan kedudukannya dalam Hukum Islam. Peneltian ini adalah peneltian kualitatif, dimana data diambil dengan Teknik wawancara kepada tetuah adat dan observasi pada pelaksanaan Martahi Mapege-pege yang dilaksanakan di Padang Lawas Utara. Setelah melakukan peneltian ini ditemukan bahwa tradisi Martahi Mapege-pege ini awalnya dilaksanakan untuk membantu mempelai laki-laki dengan tujuan untuk membantu biaya pernikahan yang meliputi biaya pelaksanaan acara Martahi Marpegepege itu sendiri, Mahar, Pakaian pernikahan, Buku nikah, Tanggatangga adat. Biaya walimatul 'ursy, Transportasi menjemput mempelai perempuan, Uang Pangolat Anak Namboruna, dan sekarang anak perempuan pun yang menikah sudah ada yang menyelenggarakan. Dari penelitian ini dapat disimpulkan bahwa tradisi martahi marpege-pege ini dalam tinjaun hokum Islam adalah termasu kepada urf Sohih karen tidak termasuk pada ibadah mahdhoh dan bersifat saling bantu-membantu antar sesama masyarakat terutama yang ekonomi lemah.

Kata Kunci: tradisi, hukum, Islam

\section{PENDAHULUAN}

Syariat Islam berarti segala peraturan agama yang ditetapkan Allah swt. .untuk umat Islam, baik dari Al-Qur'an maupun dari Sunnah Rasulullah Saw. yang berupa perkataan, perbuatan ataupun takrir (penetapan atau pengakuan). Pengertian tersebut meliputi ushuluddin (pokok-pokok agama), yang menerangkan tentang keyakinan kepada Allah berserta sifat-sifat-Nya, hari akhirat dan sebagainya, yang semuanya dalam pembahasan ilmu tauhid atau ilmu kalam. Ia juga mencakup kegiatan-kegiatan manusia yang mengarah kepada pendidikan jiwa dan keluarga serta masyarakat. Demikian pula tentang jalan yang akan membawa manusia kepada kehidupan yang sejahtera dan bahagia. Ini semuanya termasuk dalam pembahasan ilmu akhlak.

Tradisi adalah sebuah kata yang sangat akrab terdengar dan terdapat di segala suku bangsa yang ada di Indonesia. Tradisi menurut etimologi adalah kata 
yang mengacu pada adat atau kebiasaan yang turun temurun atau peraturan yang dijalankan masyarakat (KBBI, 2008: 1208). Secara langsung, bila adat istiadat atau tradisi disandingkan dengan struktur masyarakat melahirkan makna kata kolot, kuno, murni tanpa pengaruh, atau sesuatu yang di penuhi dengan sifat taqlid terhadap nenek moyang mereka.

Menikah merupakan perintah Allah swt. dan juga sunnah Rasulullah saw. yang sangat dianjurkan bagi setiap muslim dan muslimah yang sudah baligh dan sehat akalnya serta mampu untuk melaksanakannya. Allah swt. menjelaskan tentang anjuran menikah sebagaimana termaktub dalam Al-Qur'an surat An-Nisa ayat 3 sebgaimana artinya : Dan jika kamu takut tidak akan dapat berlaku adil terhadap (hak-hak) perempuan yang yatim (bilamana kamu mengawininya), maka kawinilah wanita-wanita (lain) yang kamu senangi : dua, tiga atau empat, lalu jika kamu takut tidak akan dapat berlaku adil, maka (kawinilah) seorang saja, atau budakbudak yang kamu miliki, yang demikian itu adalah lebih dekat kepada tidak berbuat aniaya. Berlaku adil dalam ayat ini ialah perlakuan yang adil dalam meladeni isteri seperti pakaian, tempat, giliran dan lain-lain yang bersifat lahiriyah. Islam memperbolehkan poligami dengan syarat-syarat tertentu. Sebelum turun ayat ini poligami sudah ada, dan pernah pula dijalankan oleh para Nabi sebelum Nabi Muhammad s.a.w. ayat ini membatasi poligami sampai empat orang saja.

Rasulullah saw. juga menjelaskan kaitannya dengan pernikahan, sebagaimana Beliau bersabda: Wahai para pemuda, barang siapa di antara kalian sudah mampu untuk menikah maka hendaklah ia menikah, karena menikah itu lebih menjaga pandangan dan memelihara kemaluan, dan barang siapa yang belum mampu maka ia harus berpuasa, maka sesungguhnya puasa itu adalah obat untuknya (Abil Hasan Muslim Bin Hujjaz Al-Qoshiri An-Naisyaburi (206-261 H), 2010: 384). Rasulullah saw sangat menganjurkan menikah bagi para pemuda yang masih lajang supaya mereka terhindar dari perbuatan yang dilarang agama.

Pada masyarakat Sumatra Utara dalam melaksanakan pernikahan melalui banyak prosesi adat seperti Horja, Mungupa, Martahi adat dan sebagainya. Tradisi-tradisi ini sudah biasa dilaksanakan sebagai bagian dari acara yang turun temurun dilaksanakan pada pesta pernikahan. Melaksanakan tradisi - tradisi semacam itu dianggap masyarakat menjadi bagian dari kemuliaan dan pada lingkungan sosial menjadi orang yang dituakan. Dari runtutan acara-acara tersebutlah maka dalam pelaksanaan pernikahan membutuhkan biaya yang cukup banyak sehingga anak muda dan keluarganya merasa terbebani akan hal 
38 | TAZKIR: Jurnal Penelitian Ilmu-ilmu Sosial dan Keislaman

Vol. 06 No. 1 Juni 2020

tersebut, maka timbullah sebuah persepsi dalam masyarakat bahwa biaya pernikahan sangat mahal, seiring juga dengan adanya pemahaman yang timbul sekarang ini semakin tinggi tingkat pendidikan anak perempuan yang akan dilamar maka semakin mahal pula boli yang harus diberikan.

Martahi Marpegepege jika dilihat dari sudut pandang adat dan budaya sama saja dengan kebisaan masyarakat yang lain akan tetapi menjadi sebuah pertanyaan besar ketika tradisi ini dilihat dari kaca mata hukum Islam, yang dikarenakan dalam pelaksanaannya ditemukan banyak yang harus dilakukan pengkajian secara mendalam dari segi hukum Islam sehingga tradisi ini apakah layak atau tidak untuk dilestarikan. Dari pelaksanaan tradisi ini, banyak manfaat yang dirasakan oleh masyarakat yaitu 1). membantu anak lajang menjadi tidak takut untuk menikah yang dikarenakan belum mempunyai kemampuan finansial, dimana biaya pernikahan yang cukup mahal.2). Orang tua yang akan menikahkan anaknya merasa terbantu dari segi finansial. 3). Dengan adanya tradisi ini maka akan mengurangi jumlah pemuda dan pemudi yang terselamatkan dari ketuaan. 4). Akan mengurangi jumlah hamil di luar nikah ataupun zina. 4). Mengurangi jumlah pernikahan yang tidak direstui (marlojong) yang mengakibatkan rusaknya kekerabatan antar masyarakat atau tatanan keluarga.

Melihat dari manfaat yang didapatkan dari pelaksanaan tradisi Martahi Marpegepege seharusnya masyarakat sudah mengakaji lebih dalam tentang tradisi ini dimana secara notabenenya masyarakat di padang lawas Utara terdapat banyak ulama yang mumpuni seugianya mampu membahas masalah ini dari aspek hukum Islam karena menurut peneliti banyak yang mesti dikaji, terutama dari segi: 1) Dari segi pembayaran uang Marpegepege dibayarkan secara sukarela akantetapi menjadi ada patokan lebih besar dari nominal yang pernah di berikan orang yang bersangkutan kepada yang ingin menikahkan anaknya waluapun secara sukarela juga. 2). Uang pemberian pada tradisi ini adalah sukarela akantetapi mambayarnya merupakan hutang. 3).Dari segi pelaksanaannya keluarga yang melaksanakan Martahi Marpegepege harus menyediakan makanan yang enak sebagai bentuk jamuan kepada para tamu yang datang. 4).Bagi anggota masyarakat yang tidak mengembalikan uang yang pernah di berikan anggota masayarakat yang lain kepadanya akan mendapatkan sanksi sosial. 5). Terkadang anggota masyarakat yang di undang pada tradisi ini ekonominya sedang tidak baik sehingga menjadi sebuah keterpaksaan bagi yang di undang. 
6). Sistem yang terbangun dalam tradisi ini masih tidak rapi sehingga terjadi ketimpangan antar anggota masyarakat dimana yang miskin mendapatkan lebih sedikit daripada yang kaya karena tidak mampu memberikan banyak. Berdasarkan gejala-gejala di atas, menjadi menarik bagi Penulis untuk melakukan penelitian terhadap tradisi Martahi Marpege pege yang sudah dilakukan oleh masyarakat Sumatera Utara secara turun-temurun.

\section{LANDASAN TEORI}

\section{Tradisi Martahi Marpege-Pege}

Sebelum dijelaskan lebih jauh tentang tradisi Martahi Marpegepege sebaiknya perlu kita jelaskan tentang pengertian tradisi itu sendiri. Dalam Kamus Besar Bahasa Indonesia tradisi diartikan sebagai segala sesuatu yang bersifatturun-temurun seperti adat, kepercayaan, ajaran, upacara, kesenian dan semacamnya (W.J.S. Poerwadarminta, 1982: 21). Dalam istilah melayu diketahui dari kamus Malaysia adalah sebagai sesuatu (adat, kebiasaan, kepercayaan, ajaran, yang turun-temurun dan sebagainya yang turun temurun dari nenek moyang (Cressent News, 1997: 1148).

Eko Endarmoko bahwa tradisi merupakan adat istiadat, etik, kebiasaan, kultur, yang bersifat turun temurun (Eko Endarmoko, 2004: 679). Hal tersebut juga senada dengan yang diungkapkan Koentjaraningrat yang mengatakan bahwa tradisi sama dengan adat. Dimana adat merupakan wujud ideal dari kebudayaan yang berfungsi sebagai tata kelakuan, karena adat berfungsi sebagai pengatur kelakuan(Koentjaraningrat, 2005: 10-11). Sedangkan budaya atau kebudayaan berasal dari bahasa sansekerta yaitu buddayah, yang merupakan bentuk jamak dari budhi (budi atau akal) diartikan sebgai hal-hal yang berkaitan dengan budhi dan akal manusia atau dengan kata lain budaya meruapakan dari keseluruhan dari dari pengetahuan, sikap dan pola prilaku yang merupakan kebiasaan yang dimiliki dan diwariskan oleh anggota sesuatu masyarakat tertentu. Banyak penulis dan peneliti membuat diskusi panjang mengenai istilah tradisi walaupun konotasinya tradisi dalam pikiran orang belanda yang terdahulu adalah keotentikan, kesinambungan dan kekunoan. Istilah tradisi yang dikaitkan dengan faktor waktu, ruang lingkup wilayah, status sosial penyangganya, serta unsur estetis di dalamnya tidak terlepas dari adat dan etnik daerah (Tati Narawati, 2001: 132). 
40 | TAZKIR: Jurnal Penelitian Ilmu-ilmu Sosial dan Keislaman

Vol. 06 No. 1 Juni 2020

Dari pengertian di atas dapat diketahui bahwa tradisi adalah hasil cipta masyarakat terhadap kebiasaan yang dilakukan oleh masyarakat terdahulu dalam satu wilayah tertentu yang kemudian diikuti oleh masyarakat selanjutnya. Tradisi dapat kita jumpai pada setiap kelompok masyarakat dalam satu wilayah perkampungan yang sudah berumur lama dalam berbagai macam bentuk. Setiap daerah atau wilayah mempunyai tradisi sendiri, dan tradisi antara satu daerah dengan daerah yang lain selalu berbeda. Perbedaan tradisi biasanya disebabkan oleh latar belakang daerah tersebut dan motivasi masyarakatnya.

Pada dasarnya tradisi biasanya dilaksanakan dalam bentuk upacara dengan menggunakan simbol-simbol kebersamaan, pemujaan sebagai dasar kepercayaan atau ajaran nenek moyang. Sebuah tradisi pada asal mulanya sesungguhnya tanpa direncanakan dan dirancang terlebih dahulu oleh masyarakatnya, akan tetapi akibat dari kebiasaan yang terus menerus dilaksanakan sehingga masyarakat selanjutnya menganggap sebuah kejanggalan moral jika tidak dilaksanakan. Pengertian tradisi itu sendiri ternyata tidak luput dari kajian Islam, sebagaimana yang dijelaskan bahwa pengertian tradisi dalam Islam adalah sebagai kepercayaan terhadap seluruh ajaran Muhammad Saw. yang tidak tertulis dalam Al-Qur'an baik berupa moral, seremoni, ataupun doktrin yang dalam bahasa Arab disebut dengan hadist atau sunnah (Thomas Patrick Hughes, 1982: 639).

Pada Masyarakat Batak Angkola yang tinggal di kabupaten Padang Lawas Utara mempunyai tradisi tersendiri sebelum menikahkan anaknya dengan mengadakan pengumpulan sejumlah uang dari karib kerabat, Dalihan Natolu dan masyarakat luas dengan tujuan untuk membantu keluarga yang akan menikahkan anak laki-lakinya. Batak angkola adalah ${ }^{1}$ adalah masyarakat suku batak yang menetap di daerah kabupaten Tapanuli Selatan dan mandailing Natal kebanyakan beragama Islam yang pada awalnya suku batak hanya satu namun kemudian setelah sekarang ini sudah terbagi-bagi dengan tujuan untuk saling membedakan (Dobbin, Christine, Tt: 25). Dalihan Natolu ialah anak boru kahanggi dan mora (anak boru : adik ipar ayah dan yang segaris dengannya, kahanggi adalah adik beradik ayah dan yang segaris dengannya, mora adalah tempat pengambilan istri dan yang segaris dengannya). Peranan dalihan Natolu dalam Proses Intraksi antara nilai-nilai adat dengan Islam pada masyarakat Mandailing dan Angkola Tapanuli Selatan (Daftar Istilah Disertasi Abbas Pulungan, 2003). Setiap daerah atau kampung sudah tentu mempunyai tradisi, 
adat, budaya masing-masing yang sedari dulu hingga sekarang masih terus dilestarikan. Tradisi dalam sebuah suku biasanya tidak diketahui kapan dimulai dan siapa yang memulainya, berbeda dengan dunia ilmu atau penemuan fosil atau sebuah pengetahuan teoritis jika ditelusuri setidaknya akan diketahui tokoh yang ada di belakangnya.

Begitulah dengan tradisi martahi marpege-pege yang ada di masyarakat Batak Angkola sampai sekarang belum diketahui siapa yang memulai pada awalnya sehingga dilaksanakan oleh masyarakatnnya sampai sekarang. Sebelum kita membahas lebih jauh tentang tradisi ini ada baiknya kita jelaskan lebih dulu pengertian martahi marpege-pege itu sendiri. Kata martahi adalah marpokat, dengar pendapat yang berasal dari bahasa Batak yang artinya adalah bermusyawarah, rapat, urun rembug. Marpege-pege juga berasal dari bahasa Batak yang artinya buah dari sebuah pohon yang bertandan, dalam satu tandan itu mempunyai banyak biji. Jadi, martahi marpege-pege jika digabungkan menjadi bermusyawarah untuk menjadi satu tandan; satu kesepakatan.

Secara terminologi martahi marpege-pege adalah tradisi markumpul hepeng (mengumpulkan uang) yang dilakukan oleh sekelompok masyarakat tertentu untuk membantu calon mempelai laki-laki menyediakan boli atau uang hantaran yang telah ditetapkan oleh pihak perempuan(Puji Kurnia, 2014: 4). Tradisi martahi marpege-pege diselenggarakan oleh calon mempelai laki-laki dengan mengundang seluruh kaum kerabat, handai taulan, dan masyarakat terdekat sebelum dilaksanakannya acara menyerahkan boli atau uang hantaran. Tradisi martahi marpege-pege dilaksanakan oleh pihak mempelai laki-laki yang ingin melaksanakan pernikahan, biasanya martahi marpege-pege ini dilaksanakan jika seorang laki-laki sudah meminang seorang perempuan yang akan dinikahinya dalam waktu dekat, dan laki-laki tersebut sudah mempertemukan antara orang tuanya dengan orang tua perempuan yang dalam pertemuan tersebut membicarakan berapa boli atau sejumlah uang yang harus diserahkan kepada pihak perempuan yang akan digunakan pada acara pesta pernikahan, sekaligus untuk membeli peralatan rumah tangga yang akan mereka pakaian nantinya sesudah menikah (B. Parningotan, 1995: 16).

Pada tradisi martahi marpege-pege anggota masyarakat saling memberikan sumbangan uang ketika ada yang ingin menikah atau menikahkan anak tanpa melihat berapa jumlah anggota keluarganya. Misalnya seseorang mempunyai empat orang anak dan yang lainnya memiliki satu orang anak saja, bahkan tidak 
atau belum ada, maka orang yang mempunyai anak empat tersebut tetap mengundang yang mempunyai anak satu dan yang belum memiliki anak tersebut walaupun untuk yang ke-empat kalinya. Martahi marpegepege dalam tinjauan hukum adat, semua tradisi dilaksanakan mempunyai nilai yang baik bagi masyarakatnya. Sebuah tradisi akan dilaksanakan oleh masyarakat suku tertentu karena terkadang sudah mendarah daging dan bahkan juga sudah menjadi bagian dari peradaban bagi masyarakat tersebut. Sebuah tradisi yang mempunyai nilai yang baik bagi masyarakatnya secara adat belum tentu baik di mata agama, karena tradisi dalam masyarakat yang dilestarikan biasanya banyak mengandung mistik atau adanya ketidaksesuaian antara ajaran agama dengan budaya tersebut. Lahirnya sebuah tradisi dalam masyarakat adalah dari nenek moyang masyarakat tersebut yang seringkali mengandung nilai sesembahan kepada makhluk gaib atau dipengaruhi oleh aliran animisme dan dinamisme.

Tradisi Martahi ini juga dapat di jadikan sebagai modal sosial yang dapat menyatukan masyarakat dari berbagai macam daerah yang ada. Tradisi ini menjadi jalan menyambungkan tali silaturahmi sehingga di angap juga sebagai modal sosial yang sangat baik dalam membangun kebersamaan. Modal sosial dinggap sebagai bagian dari penyatu masyarakat yang menyemuk dalam membangun ketahanan sosial (UI Ardaninggar Luhtitianti, 2019: 243). Banyak perbedaan dalam pergaulan masyarakat mengakibatkan terjadi gesekan sosial yang akhirnya membuat masalah baru di tengah-tengah masyarakat.

\section{Masyarakat Batak Angkola}

Batak angkola adalah salah satu suku Batak yang ada di provinsi Sumatera Utara yang biasanya berada di kabupaten Tapanuli Selatan, Padang Lawas Utara, dan kota Padang Sidempuan. Orang Batak adalah penutur bahasa Austronesia namun tidak diketahui kapan nenek moyang orang Batak pertama kali bermukim di Tapanuli dan Sumatera Timur. Kajian tentang orang batak bagian selatan atau batak angkola dapat dikatakan minim sekali jika dibandingkan dengan batak di bagian utara, bahkan yang lebih menyedihkan lagi lagi bahwa penelitian tentang batak angkola atau tapanuli selatan banyak dilakukan oleh arang luar tapanuli selatan. Penelitian-penelitian terhadap batak angkola atau mandailing mulai dilakukan oleh peneliti mulai muncul sejak tahun 1970-an dengan alasan bahwa masyarakat perantauan yang berasal dari 
tapanuli selatan mempunyai peradaban tersendiri yang berbeda dengan batak lainnya, atau setidaknya berbeda dengan apa yang sudah dipahami oleh masyarakat luas akan orang batak baik dari segi krakteristik, kondisi sosial maupun dari segi keagamaan.

Studi awal tentang batak di tapanuli selatan dilakukan oleh Herman NVDT dengan melakukan penelitian terhadap bahasa batak sehingga menerjemahkan alkitab kedalam bahasa batak tapanuli selatan (batak angkola), dan abanyak beranggapan bahwa inilah awal agama yang ada di Sumatra utara. Karya -karya yang ditulis oleh penduduk mandailing baik yang yang tinggal di daerah itu maupun yang tinggal di luar tapanuli selatan (diperantauan). Karya pertama adalah ditulis oleh putra daerah tapanuli selatan, diatantara karyanya adalah G. Siregar Baumi yang menulis tentang adat istiadat yang berlaku di seluruh wilayah tapanuli selatan ketika itu sebelum dimekarkan pada tahun 2007 yakni adat di daerah angkola, sipirok, padang bolak, barumun, batang natal, dan natal. Dalam buku ini juga dibahas tentang marga-marga, keunikan sejarah di daerah-daerah, bahasa, agama pola panggilan adat, susunan pemerintahan adat, daerah kekuasaan raja adat, mausyawarah adat, upacara-upacara adat, seni budaya, hukum adat, sampai kepada pengaruh agama terhadap adat (Abbas Pulungan, 2003: 48).

Catatan sejarah menyebutkan bahwa seorang pengembara Muslim dari Maroko yang wafat tahun 1377 (Dobbin, Christine, Tt : 240). Ia singgah di Samudera Pasai tahun $746 \mathrm{H}$ atau tahun 1345 M. Raja waktu itu Malik Al-Dzahir II (1326-1348 M), seorang yang kuat berpegang pada agama Islam dalam aliran Mazhab Syafi'i. Menurutnya Pasai telah menerima Islam dalam jangka masa satu abad sebelum kedatangannya. Samudera Pasai memang bukan kerajaan Islam pertama di Aceh. Ia adalah kerajaan kedua setelah Peureulak (Perlak) yang berdiri pada hari Selasa, 1 Muharram $225 \mathrm{H}$ dengan raja pertamanya Sultan Alaidin Saiyid Maulana Abdul Aziz Syah. Bahkan Perlak juga jadi kerajaan Islam pertama di Asia Tenggara. Setelah itu baru muncul Samudera Pasai, Kerajaan Aceh Darussalam dan kerajaan-kerajaan bercorak Islam lainnya di Indonesia seperti Malaka, Demak, Cirebon serta Ternate (Hasan Muarif Ambary, 1995: 20).

Maka dapat disimpulkan oleh penulis bahwa masyarakat batang angkola sangat kental dengan agama Islam karena jauh sebelumnya Islam sudah hadir di 
44 | TAZKIR: Jurnal Penelitian Ilmu-ilmu Sosial dan Keislaman

Vol. 06 No. 1 Juni 2020

tengah-tengah masyarakatnya. kemudian ditandai dengan adanya pondok Pesanteren Mautafawiayah di desa Purbabaru yang sudah dikenal banyan dan akrab dimasyarakat suamatra utara atau Sumatra yang sudah didirikan pada tahun 1912 samapai sekarang masih ada dan alumni-alumni sudah banyak yang menjadi ulama-ulama. Kemudian pengaruh pondok Pesanteren ini terhadap masyarakat juga sanagat besar dalam memberikan pengajaran Islam di masyarakat batak angkola karena banyak juga alumninya yang menjadi pemuka agama di kampung halamnnya setelah tamat dan pulang kekampungnya.

\section{Tradisi Dalam Perspektif Hukum Islam}

Tradisi dalam perspektif hukum Islam dikenal dengan 'urf dari kata يَعْرِن yang artinya baik dan sesuatu yang sudah diketahui oleh kalangan umum (orang banyak). Sedangkan menurut istilah 'urf adalah sesuatu yang sudah terbiasa bagi suatu masyarakat yang sudah berlaku baik segi ungkapan, perbuatan ataupun sesuatu yang dilarang yang dinamakan adat (Anwar al-baz, 2010: 234). Sedangkan Abdul Wahab Khollaf menjelaskan bahwa pada bahasa syari'at tidak ada perbedaan antara 'urf dan adat (Abdul Wahab Khollaf, 2003: 99).

Sedangkan menurut Abdul Karim Zaidah, istilah 'urf berarti ialah sesuatu yang telah dikenali oleh masyarakat dan merupakan kebiasaan di kalangan mereka baik berupa perkataan, perbuatan atau pantangan-pantangan dan juga bisa disebut dengan adat. Menurut istilah ahli syara', tidak ada perbedaan antara 'urf dan adat (adat kebiasaan). Namun dalam pemahaman biasa diartikan bahwa pengertian 'urf lebih umum dibanding dengan pengertian adat karena adat disamping telah dikenal oleh masyarakat, juga telah biasa dikerjakan di kalangan mereka, seakan-akan telah merupakan hukun tertulis, sehingga ada sanksi-sanksi terhadap orang yang melanggarnya (Muin Umar dkk,2007: 150).

Contohnya adat perbuatan, seperti kebiasaan umat manusia berjual beli dengan tukar-menukar secara langsung, tanpa bentuk ucapan akad. Adat ucapan seperti kebiasaan manusia menyebut al-walad secara mutlak berarti anak lakilaki, bukan anak perempuan dan juga kebiasaan mereka untuk tidak mengucapkan kata daging untuk ikan. Adat terbentuk dari kebiasaan manusia 
menurut derajat mereka, secara umum maupun tertentu. Berbeda dengan ijma', yang terbentuk dari kesepakatan para mujtahid saja, tidak termasuk manusia secara umum (Abdul Wahab Khollaf, 2003: 117). 'Urf atau adat itu ada dua macam, yaitu adat yang benar dan adat yang rusak. Adat yang benar adalah kebiasaan yang dilakukan manusia, tidak bertentangan dengan dalil syara', tidak menghalalkan yang haram dan tidak membatalkan kewajiban. Sedangkan adat yang rusak adalah kebiasaan yang dilakukan oleh manusia tetapi bertentangan dengan syara', menghalalkan yang haram atau membatalkan kewajiban(Muin Umar dkk,2007: 150).

Para ulama sepakat bahwa 'urf shahih dapat dijadikan dasar hujjah selama tidak bertentangan dengan syara'. Ulama Malikiyyah terkenal dengan pernyataan mereka bahwa amal masyarakat Madinah dapat dijadikan hujjah, demikian pula ulama Hanafiyah menyatakan bahwa pendapat ulama Kufah dapat dijadikan dasar hujjah. Imam Syafi'i terkenal dengan qaul qadim dan qaul jadid-nya. Ada suatu kejadian tetapi beliau menetapkan hukum yang berbeda pada waktu beliau masih berada di Makkah (qaul qadim) dengan setelah beliau berada di Mesir (qaul jadid). Hal ini menunjukkan bahwa ketiga madzhab itu berhujjah dengan 'urf. Tentu saja 'urf fasid tidak mereka jadikan sebagai dasar hujjah.

Adat yang benar, wajib diperhatikan dalam pembentukan hukum syara' dan putusan perkara. Seorang mujtahid harus memperhatikan hal ini dalam pembentukan hukumnya dan bagi hakim juga harus memperhatikan hal itu dalam setiap putusannya. Karena apa yang sudah diketahui dan dibiasakan oleh suatu masyarakat sudah barang tentu menjadi kebutuhan mereka, disepakati dan mengandung maslahat. Adat yang rusak, maka tidak boleh diperhatikan, karena memperhatikan adat yang rusak berarti menentang dalil syara' atau membatalkan hukum syara'. Hukum yang didasarkan pada adat akan berubah seiring perubahan waktu dan tempat, karena masalah baru bisa berubah sebab perubahan masalah asal. Oleh karena itu, dalam hal perbedaan pendapat ini para ulama Fikih berkata: "Perbedaan itu adalah pada waktu dan masa, bukan pada dalil dan alasan (Abdul Wahab Khallaf, 2010: 118-119). Diterimanya 'urf sebagai landasan pembentukan hukum memberi peluang lebih luas bagi dinamisasi hukum Islam. Sebab, di samping banyak masalah-masalah yang tidak 
46 | TAZKIR: Jurnal Penelitian Ilmu-ilmu Sosial dan Keislaman

Vol. 06 No. 1 Juni 2020

tertampung oleh metode-metode lainnya seperti qiyas, istihsan, dan maslahah mursalah yang dapat ditampung oleh adat istiadat ini, juga ada kaidah yang menyebutkan bahwa hukum yang pada mulanya dibentuk oleh mujtahid berdasarkan 'urf, akan berubah bilamana 'urf itu berubah.

Inilah yang dimaksud oleh para ulama, antara lain Ibnu al-Qoyyim alJauziyah (w. $751 \mathrm{H}$ ) bahwa tidak diingkari adanya perubahan hukum dengan adanya perubahan waktu dan tempat " تغيير الأحكام بتغيير الأزمان والأمكنة" maksud ungkapan ini adalah bahwa hukum-hukum fikih yang tadinya dibentuk berdasarkan adat istiadat yang baik, hukum itu akan akan berubah bilamana adat istiadat itu berubah. Ada beberapa kaidah fikhiyyah yang berhubungan dengan 'urf, diantaranya adalah: Adat itu adalah hukum العَادَةُ مُحْكَنَّة

\section{METODE PENELITIAN}

Peneltian ini adalah peneltian kualitatif, dimana data diambil dengan Teknik wawancara kepada tetuah adat dan observasi pada pelaksanaan Martahi Mapege-pege yang dilaksanakan di Padang Lawas Utara. Data penelitian diambil langsung dari masyarakat yang melaksanakan tradisi yang sedang diteliti, maka penelitian ini juga disebut Penelitian yang beranjak dari prilaku social (Skinnerian). Proses penelitian ini dilakukan dengan mengumpulkan kategori dasar yang sesuai dengan pokok persoalan lalu diteliti secermat mungkin dan dijadikan sebagai bahan untuk penyelesaian permasalahan yang sedang dibahas. Analisis yang digunakan dalam penelitian ini adalah analisis deskriftif kwalitatif, yaitu suatu analisis yang digunakan untuk memberikan deskripsi tentang perihal mengenai keadaan atau fenomena secara mendalam dari semua aspek. Metode berpikir dalam menganalisa data penelitian ini adalah dengan menggunakan metode Induktif yakni mengolah data dari suatu kaidah luas menjadi sempit atau menjadi kesimpulan khusus. Analisis penelitian ini difokuskan pada upaya penafsiran yang dilakukan secara kritis dengan memperhatikan aspek koherensi, autensitas, dan indepedensi. Pengumpulan, pencatatan dan analisa bahan empirik yang berbentuk ungkapan, pengalaman sehari-hari, struktur, wawancara, dan strategi yang dilakukan tokoh agama dan adat dalam melestarikan identitas budaya batak angkola merupakan kegiatan yang terintegrasi dalam penelitian ini. 


\section{TEMUAN DAN DISKUSI}

Setelah melakukan peneltian di temukan bahwa martahi atau marpokat adalah bermusyawarah, rapat, urun rembug. Marpege-pege pada adat batak Angkola yang artinya buah sebuah pohon yang beranting-ranting, dalam satu ranting itu terdiri banyak biji. Jadi, jika digabungkan menjadi Martahi Marpegepege yakni bermusyawarah untuk menjadi satu ranting, satu kesepakatan. Dalam pengertian secara terminologinya Martahi Marpege-pege adalah tradisi markumpul hepeng (mengumpulkan uang) yang dilakukan oleh sekelompok masyarakat tertentu yang ada di kabupaten Padang Lawas Utara dalam rangka untuk membantu calon mempelai laki-laki dalam membayarkan boli atau uang hantaran yang telah ditetapkan oleh pihak perempuan (Puji Kurnia, 2014: 4). Tradisi Martahi Marpege-pege diselenggarakan oleh calon mempelai laki-laki dengan mengundang seluruh kaum kerabat, handai taulan, dan masyarakat terdekat sebelum dilaksanakannya acara menyerahkan boli atau uang hantaran.

Kegiatan mengumpulkan uang diadakan dengan sebutan Martahi Marpegepege, dimana masyarakat yang terdiri keluarga besar, Dalihan Natolu dan masyarakat luas yang kita kenal berdatangan memberikan sejumlah uang untuk membantu meringankan beban keluarga. Kegiatan ini dilaksanakan pada awalnya hanya bagi keluarga anaknya laki-laki yang menikah dengan tujuan untuk membantu boli kemudian sekarang ini keluarga yang mempunyai anak perempuan pun sudah ada yang ikut melaksanakannya akan tetapi masih sangat jarang karena pada hari walimahannya para tamu undangan sudah membawakan kado yang kalau di daerah Padang Lawas Utara, Sipirok, padang sidempuan dan sekitarnya membawa Abit (kain sarung).

Sebenarnya dari wawancara yang di dapatkan peneliti bahwa Pernikahan di daerah Sumatra utara secara umum dan daerah-daerah tertentu secara khusus sudah lama diketahui oleh masyarakat luas bahwa biaya pernikahan sangat mahal dengan catatan bahwa banyak yang harus disiapkan dan biayai oleh pihak laki-laki sebelum melaksanakan pernikahan. Diantara yang harus dibiayai oleh pihak laki-laki mencakup kepada: Biaya Manyapai atau menanyakan mempelai perempuan apakah mau menikah dengan mempelai laki-laki dan dalam acara inilah kegiatan menyepakati boli yang dalam hal ini calon mempelai laki-laki harus membawa keluarga besarnya dan tokoh masyarakat yang ada di kampungnya (B. Parningotan 2010: 67). Biaya pelaksanaan acara Martahi Marpegepege, karena dalam acara ini sanak saudara atau masyarakat luas yang 
48 | TAZKIR: Jurnal Penelitian Ilmu-ilmu Sosial dan Keislaman

Vol. 06 No. 1 Juni 2020

datang harus di jamu dengan makanan yang enak, Mahar, Pakaian pernikahan, Buku nikah, Tangga-tangga adat atau biaya yang di keluarkan oleh pihak laki-laki diluar mahar pada acara resepsi pernikahan ((B. Parningotan 2010: 97). Biaya walimatul 'ursy yang diselenggarakan di rumah perempuan jikalau hanya pesta biasa mungkin sekitar Rp. 15.000.000,00 ke atas akantetapi jika Horja maka biayanya sekitar Rp. 50.000.000,00, Transportasi menjemput mempelai perempuan. Biaya transportasi ini menjadi mahal karena keluarga pihak laki-laki wajib datang secara adat beserta Dongan Sahuta (sebagian masyarakat yang ada di kampung laki-laki yang terdiri dari unsur bagian Raja Kampung, Hatobangon (tokoh masyarakat), ibuibu, Naposobulung dan Naulibulung (pemuda dan pemudi tempat kita tinggal) sebagai rombongan, Uang Naposobulung dan Naulibulung yang ada di kampung mempelai perempuan. Uang ini diberikan kepada ketua pemuda dan pemudi yang ada dikampung mempelai perempuan dengan alasan sebagai ganti jerih payah mereka dalam menyukseskan acara resepsi pernikahan tersebut, Uang Pangolat Anak Namboruna yaitu sejumlah uang yang diberikan kepada anak namborunya perempuan (anak laki-laki dari adik perempuan bapak yang biasanya digadang-gadang akan menikah dengan anak tersebut) dengan alasan sebagai balasan baginya sudah menjaga mempelai perempuan selama ini, Biaya pesta di tempat laki-laki.

Biaya-biaya diatas secara keseluruhan ditanggung oleh pihak laki-laki karena sudah menjadi tanggung jawabnya sebagai laki-laki atau keluarga sehingga biaya yang harus dikeluarkan oleh pihak laki-laki menjadi sangat banyak dan mahal sementara sebagian besar pekerjaan atau usaha masyarakat Batak Angkola yang tinggal di Kabupaten Padang Lawas Utara adalah petani padi dan Karet, dan keadaan inilah yang menjadi latar belakang terpenting kenapa kegiatan Martahi Marpegepege ini selalu diadakan oleh masyarakat yang ada di Kabupaten padang lawas utara ketika seorang anak laki-laki ingin melangsungkan pernikahan.

Tradisi Martahi Marpegepege dilaksanakan dengan beberapa tahapan sebagaiamana berikut ini:

1. Musyawarah Sabagas, dimana mayawarah sekelurga besar yang terdiri dari Kahanggi (keluarga besar yang terdiri dari ayah dan ibu, kakak ayah lakilaki, kakak ayah perempuan, ade ayah laki-laki dan perempuan begitu juga kakak dan ade ibu laki-laki dan perempuan), dalam musyawarah ini yang di bicarakan adalah kapan pergi menindak lanjuti Khobar (pembicaraan) kepihak perempuan tentang berapa Boli, konsep acara walimah 
dilaksanakan dan hal-hal penting yang berhubungan dengan Walimatul 'ursy.

2. Pagogo Khobar, setelah berapa boli baru disepakati kapan Martahi Marpegepege dilaksanakan dengan tujuan agar ada dana tambahan pada acara pernikahan nantinya.

3. Hari pelaksanaan, maka berdatanganlah keluarga besar dan masyarakat luas mengantarkan uang pemberiannya kerumah orang yang sedang melaksanakan Martahi Marpegepege dan keluarga pelaksana wajib memberikan jamuan yang baik. Setiap orang yang memberikan uang dicatat dengan baik sehingga diketahui apakah setiap orang yang pernah kita berikan uang Pegepege dikembalikannya.

4. Setelah selesai acara baru dihitung total uang yang terkumpul yang kemudaian diserahkan kepada pihak perempuan sesuai dengan jumlah Boli yang disepakati di awal.

5. Jika seandainya uang yang terkumpul pada waktu acara Martahi Marpegepege tadi ada sisanya maka uang itulah yang digunakan untuk biayabiaya yang lain seperti transportasi dan lain-lain.

6. Jika uang yang terkumpul ternyata hanya sedikit maka kekukarangannya akan ditanggung oleh pihak laki-laki sendiri.

Setelah peneliti melakukan analisa dari aspek pelaksanaan tradisi Martahi Marpegepege ini, peneliti menemukan bahwa dari segi pelaksanaan tradisi ini, lebih menitik beratkan kepada motivasi dari masyarakat dalam melaksanakan tradisi Martahi Marpegepege untuk membantu pemuda untuk melaksanakan sunnah Rasul sallahu alaihi wasallam atau menikah, dimana di kabupaten Padang Lawas Utara biaya pernikahan sangat mahal, maka hal ini menjadi sesuatu yang baik dan tidak menyalahi hukum. Kegiatan ini menurut peneliti tidak melangggar Syari'at Islam dengan alasan bahwa sesuatu yang baik apalagi sifatnya membantu atau tolong menolong antar sesama masyarakat merupakan cerminan dari perintah Allah subahana wata'ala.

Dalam menganalisa penelitian ini yakni Tradisi Martahi Marpegepege dalam tinjauan hukum Islam menjadi sangat menarik karena tradisi ini sudah ada sejak jaman dahulu kala dan sudah mendarah daging bagi penduduk di Kabupaten Padang Lawas Utara Provinsi Sumatra Utara. Tujuan yang sangat mendasar dari pelaksanaan tradisi Martahi Marpegepege adalah untuk membantu keluarga yang ingin menikahkan anaknya dimana dalam pernikahan tersebut 
50 | TAZKIR: Jurnal Penelitian Ilmu-ilmu Sosial dan Keislaman

Vol. 06 No. 1 Juni 2020

banyak harus di biayai oleh pihak laki-laki yakni membayar mahar, Boli, dan tangga-tangga adat dan biaya-biaya lainnya. Tradisi ini juga menjadi penting dalam kehidupan masyarakat dalam melaksanakan ajaran agama dan menghidar dari perzinahan. Salah satu tujuan dari pernikahan menurut Maqosid Syariah adalah untuk menjaga keturunan atau diri (hifzud diin). Tradisi ini sudah berjalan begitu lama dan mempunyai pengaruh yang positif dalam membangun masyarakat yang damai dan tolong mononlong maka penting di telusuri menurut pandangan hukum Islam. Sebagai landasan bahwa Maqosid Syariah merupakan dasar untuk pembentukan hukum Islam dan penerapannya, baik ibadah, muamalah, dan moralitas (Zul Anwar Azim Harahap, 2014: 171), tradisi ini masuk kepada muamalah.

Dari penjelasan diatas dapat diketahui bahwa maharlah yang wajib dibayar oleh seorang suami kepada istri yang tidak lain berdasarkan kesanggupan dan kemampuan seorang suami bukan Boli (sejumlah uang diluar mahar) dan yang lain-lain sehingga memberatkan pihak laki-laki. Dan Islampun tidak memberikan batasan beasaran mahar bahkan maharpun tidak harus dibayar kontan bahkan boleh di hutang dan boleh dengan benda-benda yang bermanfaat (Mustafa alkind, 1987: 88). Mahar dan Boli dalam adat masyarakat di Kabupaten Padang Lawas Utara adalah satu kesatuan yang tidak dapat dipisahkan, karena dalam prakteknya kedua hal tersebut memiliki posisi yang sama dalam hal kewajiban yang harus dipenuhi oleh mempelai laki-laki. Boli dalam pandangan adat di Kabupaten Padang Lawas Utara mendapatkan perhatian yang lebih dalam perbincangan masyarakat luas dan bahkan boli dapat menjamin lancarnnya pesta pernikahan, karena semakin besar Bolinya maka semakin megah pesta pernikahannya.

Setelah menganalisa kajian tentang tradisi Martahi Marpegepege dalam tinjauan Hukum Islam peneliti mengumpulkan beberapa unsur yang terdapat di dalamnya yang merupakan nilai kebaikan untuk dianalisa lebih dalam diantaranya adalah:

a. Budaya Tolong Menolong, Tradisi Martahi Marpege-pege merupakan bagian dari kegiatan tolong menolong antar anggota masyarakat dalam rangka untuk meringankan beban sesama dalam menjalankan perintah Allah Swt yang berarti adalah sebuah kebaikan (Al-Qur an, Surat Al-Maidah: 2).

b. Silaturrahmi, Pembinaan silaturrahmi dapat dilakukan melalui pelaksanaan tradisi Martahi Marpegepege karena dengan tradisi ini sesama kerabat, 
tetangga, sanak saudara menjadi saling mengunjungi. Silaturrahmi antara yang dekat menjadi semakin dekat dan yang jauh menjadi dekat. Silaturrahmi sangat penting dalam kehidupan bermasyarakat karena tidak satu pun manusia yang bisa hidup sendiri tanpa bantuan orang lain karna manusia adalah zoon Piliticon (manusia yang saling membutuhkan).

c. Hutang piutang, Uang pemberian dalam tradisi Martahi Marpegepege menjadi hutang seperti biasanya dimana orang yang mendapat pemeberian harus mengembalikannya dikemudian hari. Utang piutang secara hukum dapat didasarkan pada adanya perintah dan anjuran agama supaya manusia hidup dengan saling tolong menolong serta saling bantu membantu dalam lapangan kebajikan (Moh. Yasir, 2005: 18). Hal hutang piutang dalam agama Islam sesuatu yang diperbolehkan dan sudah diatur sedemikian rupa sehingga sistem dan aturannya sudah ada dan baku didalam Al-qur'an

\section{KESIMPULAN}

Dari penjelasan diatas dapat dipahami bahwa suatu maslahah itu dapat dijadikan hujjah dalam menetapkan hukum selama tidak bertentangan dengan syarai'at yang ada. Seperti halnya tradisi Martahi Marpegepege yang sudah terlaksana di Kabupaten Padang Lawas Utara menjadikan maslahah sebagai alasan hujjah dalam menetapkan hukumnya menjadi 'urf shahih karena peneliti berkeyakinan bahwa mashlahah yang terkadung didalam tradisi Martahi Marpegepege sengat banyak diantaranya sikap tolong menolong antar sesame masyarakat dalam membantu saudaranya yang merasa kesulitan biaya dalam melakasanakan pernikahan.

Banyak kemaslahatan dari tradisi Martahi Marpegepege yang merupakan kemudahan sesorang dalam melaksanakan pernikahan yang juga menjadi bagian dari kemaslahatan itu sendiri seperti memelihara agama dengan melaksanakan pernikahan, dimana bahwa pernikahan sama halnya setengah agama, memelihara jiwa, memelihara akal, memelihara keturunan dan memeliahara benda. Kemudian jika dilihat dari keberadaan Mashlahah yang ada pada tradisi Martahi Marpegepege termasuk kepada mashlahah al-dharuriyyah yaitu kemaslahatan yang berhubungan dengan kebutuhan pokok manusia di dunia dan akhirat, dan kemaslahatan yang dimasksud meliputi lima yaitu memelihara agama, memelihara jiwa, memelihara akal, memelihara keturunan dan memeliahara benda (Maimoen Zubair, 2009: 267). Dan posisi tradisi ini dalam 
52 | TAZKIR: Jurnal Penelitian Ilmu-ilmu Sosial dan Keislaman

Vol. 06 No. 1 Juni 2020

hokum Islam kepada 'urf al-shahih yaitu kebiasaan yang berlaku ditengahtengah masyarakat yang tidak bertentangan dengan nash (ayat atau hadist), tidak menghilangkan kemaslahatan mereka, dan tidak pula membawa mudarat kepada mereka. Juga karena di dalamnya tidak ada unsur untuk mengharamkan yang halal dan tidak menghalalkan yang haram.

Hukum Islam mengakui adat atau tradisi menjadi sumber hukum karena sadar akan kenyataan yang ada bahwa adat kebiasaan telah mendapatkan peranan yang penting dalam mengatur lalu lintas hubungan antar social masyarakat. Adat kebiasaan berkedudukan pula sebagai hukum tertulis dan dipatuhi karena dirasakan sesuai dengan keadaan masyarakat setempat dan juga tidak menyalahi Aqidah mereka, sebagimana Kaidah Fiqhiyah :Al-Adatu Muhakkamah: Adat kebiasaan dapat dijadikan sebagai pijakan hukum (Wahbah Alzuhaili, 1986: 799-800). 


\section{DAFTAR PUSTAKA}

Abdul Syani. (1995) Sosiologi dan Perubahan Masyarakat, Ed. 1, Pustaka Jaya: Jakarta.

Abil Hasan Muslim Bin Hujjaz Al-Qoshiri An-Naisyaburi, (2010). Shohih Muslim, (Kitabun Nikah), Cet-I, Darul Ibnu Hazm: Kairo.

Abdul Wahab Khallaf. (2010). Ilmu Ushul Fiqh (kaidah hukum Islam), Jakarta: Darattarast.

Abbas Pulungan. (2003). Peranan dalihan Natolu dalam Proses Intraksi antara nilainilai adat dengan Islam pada masyarakat Mandailing dan Angkola Tapanuli Selatan, Disertasi. IAIN Sunan Kalijaga. Yogyakarta.

Abdul Wahab Khollaf. (2003). Ilmu Ushulul Fiqhi. Daarul Hadist. Kairo.

Anwar Al-Baz (2010). Mu'zam Musthalahtil Al-Ulum As-Syar'iyah, Cet. I. darul Wafa: Mesir.

Anwar Haryono (1988). Hukum Islam Keluasan dan Keadilannya, Bulan Bintang: Jakarta.

B. Parningotan. (1995). Kamus Batak, Edisi -1. Cet-1, Sumatra Utara: Medan.

Cressent News. (1997). Kamus AM (Kamus paling Menyeluruh Ketika Ini, Cet. I. Cresent News (K.L) SDN. BHD: Kuala Lumpur,

Dobbin, Christine. Tt. Gejolak Ekonomi, Kebangkitan Islam, dan Gerakan Paderi, Minangkabau 1784 - 1847.

Eko Endarmoko (2004). Tesaurus Bahasa Indonesia, PT. Grapindo: Jakarta.

Koentjaraningrat. (2005). Kebudayaan Mentalitas dan Pembangunan, PT. Grapindo. Jakarta.

M. Idris Ramulyo. (1984). Beberapa Masalah Tentang Hukum Acara Peradilan Agama dan Perkawinan Islam, Hill.Co: Jakarta.

Muin Umar dkk. (2005) Ushul Figh 1, Depag: Jakarta.

Muhammad abu zahrah,t.t, Usul Fiqih, Dar al-fikri ‘arabiy. Cairo.

Muhammad al-Bahi, Tt, Al-fikr al-Islamy wa al-Mujtami' al-Ma'ashir, Dar alQoumiyah: Jakarta.

Maimoen Zubair. (2009). Formulasi Nalar Fiqhi, Kalistha: Surabaya. 
54 | TAZKIR: Jurnal Penelitian Ilmu-ilmu Sosial dan Keislaman Vol. 06 No. 1 Juni 2020

Mustafa alkind. (1987). Fiqh Al-manhaji. Edisi IV. Darul Qolam: Damaskus,

Moh. Yasir. (2005) Fiqih, CV. Sahabat: Klaten.

Muhammad abu zahrah, t.th, Usul Fiqih, Dar al-fikri ‘arabiy: Cairo.

Puji Kurnia. (2014). Mengakhiri Pertentangan Budaya dan Agama, Cet I. Pustaka Aura Semesta. Bandung.

Tati Narawati. (2001). Seni dan Pendidikan Seni Rampai, Grapindo: Jakarta.

UI Ardaninggar Luhtitianti. (2019). Islam and Local Tradition, A Sosial Capital To Strengthening Urban Developmen In Kampung Yogyakarta, Fitrah, Vol. 5 No.2. p. $243 . \quad$ http://jurnal.iainpadangsidimpuan.ac.id/index.php/F/article/view/1871/1638. Diakses tgl 03 Agustus 2020

W.J.S. Poerwadarminta. (1982). Kamus Umum Bahasa Indonesia, Balai Pustaka: Jakarta.

Zul Anwar Azim Harahap. (2014). Konsep Maqosid Syariah Sebagai dasar penetapan dan penerapan dalam hukum islam menurut 'izzuddin bin 'abd Al-Salam (w.660 H), Tazkir, Vol.9 No. 2. Hal. 171 http://jurnal.iainpadangsidimpuan.ac.id/index.php/TZ/article/view/108/97, Diakses tgl 03 Agustus 2020 